\title{
Somatostatin analogue in short term management of hyperinsulinism
}

\author{
J M W KIRK, L DI SILVIO, P C HINDMARSH, AND C G D BROOK
}

\author{
Endocrine Unit, Middlesex Hospital, London
}

SUMMARY Five infants with hypoglycaemia due to hyperinsulinism were treated for between three and 11 days with a somatostatin analogue, which raised the mean blood glucose concentration and lowered the glucose requirements in all. Somatostatin analogue appears to be useful in the short term management of these patients.

The prompt and effective treatment of hypoglycaemia due to hyperinsulinism reduces substantially the risk of long term neurological sequelae. ${ }^{1}$ Glucose alone, even in high concentrations, may often fail to maintain blood glucose concentrations within the normal range and other measures are required to reduce the excessive concentrations of insulin. ${ }^{1}$

Diazoxide has been used but this drug has major side effects and may be ineffective, especially in younger patients. Natural sequence somatostatin reduces insulin concentrations but its therapeutic use is limited by its half life of only two to three minutes so that it is necessary to administer it by continuous intravenous infusion. ${ }^{2}$

We have used long acting somatostatin analogue (SMS 201-995, Sandoz), which is more potent and specific than the natural peptide and can be given by subcutaneous injection, to treat five patients with hypoglycaemia due to hyperinsulinism.

\section{Patients and methods}

All patients were girls: four presented within a few hours of birth; the fifth presented at 9 months of age but gave a history from birth of hypoglycaemic symptoms, which had responded to two hourly feeds both day and night. Birth weights were above the 50th centile for gestational age (table).

Spontaneous hypoglycaemia with inappropriately raised concentrations of insulin and without keto- nuria was confirmed in all patients. Four proceeded to laparotomy with subtotal (95-98\%) pancreatectomy; histological features of nesidioblastosis were seen in three specimens and the fourth had those of insulinoma. The fifth patient, whose blood glucose concentrations were easier to control than those of the other patients, recovered normal blood glucose concentrations over a period of several weeks.

Blood glucose concentrations were measured hourly using the YSI Model 23A Glucose Analyser (Yellow Spring Instruments). Plasma insulin concentrations were estimated by a two antibody immunoassay. $^{3}$

\section{Results}

A test dose of somatostatin analogue $(1.0 \mu \mathrm{g})$ was administered subcutaneously to patient 1 . Within minutes there was a rapid rise in blood glucose concentration and a concomitant reduction in glucose requirements, with the effect waning after four to five hours. ${ }^{4}$

Somatostatin analogue was then administered subcutaneously in three to four doses per day, commencing at $1.0 \mu \mathrm{g} / \mathrm{kg} /$ dose, but subsequently titrating the dosage against response, for a total of three to 11 days. Increasing doses of analogue led to a fall in glucose requirements (although never into the normal range for infants of $4-6 \mathrm{mg} / \mathrm{kg} /$ minute) and to a reduction of glucose oscillation. All patients continued to require intravenous treatment.

The figure (a) shows that in all patients the mean 24 hour blood glucose concentration rose after the administration of somatostatin analogue $(4-9 \mu \mathrm{g} / \mathrm{kg} /$ day). The change in mean 24 hour blood glucose concentrations was significant (Wilcoxon's paired test; $p<0.05)$, although the change in glucose oscillation was not. Glucose requirements fell significantly $(\mathrm{p}<0 \cdot 05)$ (figure (b)).

Table Details of patients

\begin{tabular}{|c|c|c|c|c|c|c|}
\hline $\begin{array}{l}\text { Patient } \\
\text { No }\end{array}$ & $\begin{array}{l}\text { Age at } \\
\text { presentation }\end{array}$ & $\begin{array}{l}\text { Birth } \\
\text { weight }(g)\end{array}$ & $\begin{array}{l}\text { Gestation } \\
\text { (weeks) }\end{array}$ & $\begin{array}{l}\text { Glucose } \\
\text { (mmol/l) }\end{array}$ & $\begin{array}{l}\text { Insulin } \\
(m U / l)\end{array}$ & Diagnosis \\
\hline 1 & Birth & 2610 & 36 & 0.4 & $24 \cdot 1$ & Nesidioblastosis \\
\hline 2 & Birth & 4380 & 36 & $1 \cdot 1$ & $29 \cdot 0$ & Nesidioblastosis \\
\hline 3 & 9 months & 4000 & 40 & $1 \cdot 5$ & $21 \cdot 1$ & Nesidioblastosis \\
\hline 4 & Birth & 4460 & 39 & $0 \cdot 5$ & $72 \cdot 0$ & Insulinoma \\
\hline 5 & Birth & 2970 & 36 & $0 \cdot 8$ & $26 \cdot 2$ & $\begin{array}{l}\text { 'Transient' } \\
\text { hyperinsulinism }\end{array}$ \\
\hline
\end{tabular}






Figure The effect of somatostatin analogue on (a) mean 24 hour blood glucose concentration and (b) 24 hour blood glucose requirements in the five patients.

\section{Discussion}

Somatostatin analogue was effective in the short term management of patients with hypoglycaemia due to hyperinsulinism. We use it to stabilise blood glucose concentrations and to enable lower concentrations of glucose to be used both preoperatively and perioperatively. Given by regular subcutaneous injection its dosage regimen can be easily titrated against response and its short onset of action enables it to be of use in the emergency management of these patients, such as in the resiting of drips.

There are some theoretical reservations about the long term administration of somatostatin analogue to children as it has profound effects on many other hormones. ${ }^{56}$ Until the long term effects of somatostatin analogue are known, the treatment of choice in severe infantile hyperinsulinism should remain surgical, with maximal pancreatectomy. Premedication with somatostatin analogue greatly facilitates blood glucose control during the procedure.

References

1 Aynsley-Green A, Polak JM, Bloom SR, et al. Nesidoblastosis of the pancreas; definition of the syndrome and management of the severe neonatal hyperinsulinaemic hypoglycaemia. Arch Dis Child 1981;56:496-509.

${ }^{2}$ Hirsch HJ, Loo S, Evans N, Crigler JF Jnr, Filler RM, Gabbay HK. Hypoglycaemia of infancy and nesidioblastosis; studies with somatostatin. N Engl J Med 1977;296:1323-6.

${ }^{3}$ Morgan CR, Lazarow A. Immunoassay of insulin; a two antibody system. Diabetes 1963;12:115-26.

${ }^{4}$ Hindmarsh PC, Brook CGD. Short-term management of nesidioblastosis using the somatostatin analogue SMS 201-995. $N$ Engl J Med 1987;316:221-2.

5 Adrian TE, Barnes AJ, Long RG, et al. The effect of somatostatin analogues on secretion of growth, pancreatic and gastro-intestinal hormones. J Clin Endocrinol Metab 1981;53: 675-81.

${ }^{6}$ Aynsley-Green A, Barnes ND, Adrian TE, Kingston J, Boyes S, Bloom SR. Effect of somatostatin infusion on intermediary metabolism and entero-insular hormone release in infants with hyperinsulinaemic hypoglycaemia. Acta Paediatr Scand 1981;70: 889-95.

Correspondence to Dr C G D Brook, Endocrine Unit, Middlesex Hospital, London W1N 8AA.

Accepted 15 July 1988

\title{
Recurrent pancreatoblastoma with inappropriate adrenocorticotrophic hormone secretion
}

\author{
S J PASSMORE, P J BERRY, AND A OAKHILL \\ Bristol Royal Hospital for Sick Children, St Michael's Hill, Bristol
}

SUMMARY We describe a boy with recurrent pancreatoblastoma who developed Cushing's syndrome due to inappropriate adrenocorticotrophic hormone secretion.

Primary epithelial tumours of the pancreas are rare in childhood. Although islet cell tumours have previously been shown to produce inappropriate secretion of peptide hormones, we believe that this is the first report of a pancreatoblastoma producing adrenocorticotrophic hormone and an ectopic hormone syndrome.

\section{Case report}

A 22 month old boy presented with a firm, non- 